\title{
PELATIHAN KOMPETENSI KOMUNIKASI UNTUK PEBISNIS PEMULA
}

\author{
Fatmawati Moekahar'), Benni Handayani'), Yudi Daherman ${ }^{3)}$, \\ Mufti Hasan Alfani ${ }^{4)}$ \\ Universitas Islam Riau ${ }^{1)}$ \\ Universitas Islam Riau ${ }^{2}$ \\ Universitas Islam Riau ${ }^{3)}$ \\ Universitas Islam $\mathrm{Riau}^{4}$ \\ fatmawatikaffa@com.uir.ac.id ${ }^{1}$
}

\begin{abstract}
ABSTRAK
Keterampilan komunikasi menjadi modal penting bagi para entrepreneur muda dalam merintis dan membangun sebuah bisnis. Selain memiliki jiwa pengusaha, pebisnis pemula juga diharapkan memiliki kompetensi komunikasi. Kompetensi komunikasi bukan hanya diperlukan untuk berhadapan langsung dengan calon konsumen tetapi juga bagaimana berkomunikasi melalui media. Kegiatan ini dalam bentuk pelatihan kompetensi komunikasi untuk pebisnis pemula. Pelatihan ini bertujuan untuk meningkatkan kompetensi komunikasi bagi para tenant yang merupakan mahasiswa dan alumni di Universitas Islam Riau. Kegiatan pelatihan terdiri atas 3 tahap, yakni: Brainstorming, Pelatihan dan Monitoring \& Evaluasi. Kegiatan brainstorming dilakukan untuk menggali lebih dalam masalah yang dihadapi oleh para peserta, terutama masalah komunikasi. Sesi I fokus pada keterampilan komunikasi entrepreneur (baik secara langsung maupun by media) dan sesi II adalah presentasi bisnis para tenant. Kegiatan pelatihan ini sangat berguna bagi para pebisnis pemula karena dapat meningkatkan keterampilan komunikasi sebagai pebisnis. Kegiatan Monitoring dan Evaluasi dilakukan dengan melakukan observasi dan wawancara secara langsung kepada peserta terkait kompetensi komunikasi yang dimiliki oleh peserta setelah mengikuti kegiatan pelatihan kompetensi komunikasi.
\end{abstract}

Kata kunci: Kompetensi Komunikasi, Pelatihan, Pebisnis Pemula.

\begin{abstract}
Communication skills are an important asset for young entrepreneurs in pioneering and building a business. In addition to having an entrepreneurial spirit, a beginner business are also expected to have communication competencies. Communication competence is not only needed to deal directly with potential customers but also how to communicate through the media. This activity is in the form of communication competency training for novice business people. This programs is in the form of communication competency training for a beginner business. This training aims to improve communication competence for tenants who are students and graduated at Universitas Islam Riau. Training activities consist of 3 stages:: Brainstorming, Training and Monitoring \& Evaluation. This training activity is very useful for a beginner businessmen because it can improve communication skills as a businessman. Brainstorming activities were carried out to dig deeper into the problems faced by the participants, especially communication problems. Session I focused on entrepreneurial communication skills (both in person and by media) and the second session focused on business presentations for tenants. Monitoring and evaluation activities are carried out by conducting direct observations and interviews with participants regarding the communication competences possessed by participants after participating in communication competency training activities.
\end{abstract}

Keywords: Communication Competence, Training, and A Beginner Businessmen

\section{PENDAHULUAN}

Perkembangan teknologi komunikasi yang begitu cepat, diiringi dengan kemudahan berinvestasi bagi investor asing di Indonesia, menjadi pemicu bagi lulusan perguruan tinggi untuk siap berkompetitif. Oleh karena itu, menciptakan sarjana yang cerdas, berjiwa entrepreneur, kreatif dan inovatif merupakan kewajiban bagi perguruan tinggi saat ini.
Universitas Islam Riau merupakan kampus yang telah memiliki jumlah mahasiswa sebanyak lebih kurang 25.000 orang. Dari jumlah tersebut, sangat berpeluang untuk menumbuhkan jiwa enterpreneur kepada mahasiswa. Passion berwirausaha muncul pada usia 18 - 24 tahun (Merieska \& Meiyanto, 2017). Kewirausahaan adalah komponen vital dalam pertumbuhan ekonomi suatu bangsa (Noya, 2017). Remaja tidak 
hanya sibuk bermedia social saja, tetapi memiliki kreativitas yang dapat menghasilkan dan menopang kehidupannya. Hasil penelitian mengatakan bahwa literasi media di Pekanbaru masih tergolong cukup minim, yakni di tingkat technical skill saja (Moekahar \& Handayani, 2019). Peningkatan softskill remaja perlu dilakukan.

Langkah awal yaitu mengupayakan untuk merubah paradigma berpikir masyarakat terhadap lulusan perguruan tinggi, khususnya lulusan sarjana strata satu (S1) dari pekerja/karyawan menjadi seorang pengusaha harus segera diubah. Padahal jika dipahami, lulusan S1 itu disiapkan untuk menjadi seorang analis, pengusaha muda yang memiliki kemampuan analisis yang mumpuni. Sehingga kurang tepat jika seorang sarjana hanya disiapkan sebagai tenaga teknis semata. Masih terbatasnya fasilitas berwirausaha bagi mahasiswa membuat jiwa enterpreneurship hanya tumbuh secara otodidak pembelajaran kewirausahaan yang masih bersifat konseptual, bahan ajar yang belum mampu menjawab tantangan zaman serta modul pembelajaran yang bersifat konvensional menjadi persoalan utama dalam pengembangan wirausaha mahasiswa. Langkah strategis yang mesti dilakukan perguruan tinggi adalah dengan melahirkan sarjana yang cerdas, berjiwa wirausaha, kreatif dan inovatif.

Keterampilan komunikasi menjadi modal penting bagi para entrepreneur muda dalam merintis dan membangun sebuah bisnis. Selain memiliki jiwa pengusaha, pebisnis pemula juga diharapkan memiliki kompetensi komunikasi. Universitas Islam Riau melalui Kegiatan Pengabdian Masyarakat yang dilakukan oleh Tim Dosen dalam Program Pengabdian Masyarakat (PPK) tahun 2020 melakukan kegiatan pendampingan Kewirausahaan terhadap para mahasiswa dan alumni Universitas Islam Riau. Program tersebut memiliki beberapa kegiatan yang fokus untuk memberikan capacity building terhadap para tenant yang terpilih. Artikel ini focus pada salah satu kegiatan PPK, yakni Pelatihan Kompetensi Komunikasi bagi Pebisnis Pemula. Kegiatan ini bertujuan untuk memberikan pelatihan kompetensi bagi mahasiswa dan alumni Universitas Islam Riau sebanyak 20 orang. Peserta pelatihan merupakan pebisnis pemula yang baru memulai wirausaha baik di bidang produk maupun jasa.

Saat ini telah banyak muncul para pebisnis kreatif yang berasal dari para pemuda, termasuk mahasiswa. Kreativitas yang dimiliki oleh mahasiswa perlu mendapatkan dukungan keterampilan komunikasi sebagai pebisnis. Karena berbisnis adalah upaya "menjual diri". Jika seorang pebisnis mampu melakukan komunikasi bisnis yang baik terkaat produk yang dijualnya, maka hal tersebut akan dapat menunjang kesuksesan bisnis yang digelutinya. Di beberapa daerah telah dilakukan peningkatan kapasitas entrepreneur melalui pelatihan dan magang (Sulistiyowati, Agustini, \& Fitriyah, 2016); Pelatihan (Agustin, Dyan, Dwi, 2020) Komunikasi efektif (Marganingsih, Pelipa, \& Astuti, 2018); dan Pengaruh Model Komunikasi, Pembelajaran dan Sikap Kewirausahaa (Rakib, 2010). Dalam kegiatan pengabdian kepada masyarakat yang dilakukan ini fokus pada entrepreneur muda yang telah memiliki bisnis yang baru berdiri atau dirintis ( $1-3$ tahun). Para pebisnis pemula ini masih memiliki beberapa kekurangan, diantaranya: Keterampilan Komunikasi, Komunikasi Pemasaran, dan Skill Manajerial. Artikel ini hanya membahas satu diantara tiga permasalahan utama yang dialami oleh para Entrepreneur muda di Universitas Islam Riau. keterampilan komunikasi merupakan bentuk softskill remaja yang dapat meningkatkan diferensiasi dan komptensi (Moekahar, Sukri, \& Amalia, 2020). 


\section{METODE PELAKSANAAN}

Pelaksanaan program ini terdiri dari 3 tahap, yakni: a) Tahap Brainstorming, b) Tahap Peningkatan Kapasitas melalui Pelatihan dan Magang, c) Tahap Monitoring dan Evaluasi Program. Sasaran dalam program ini adalah 20 mahasiswa dan alumni Universitas Islam Riau yang memiliki bisnis berjalan yang berusia ( $1-3$ tahun).

Pada tahap awal program ini dilakukan brainstorming. Brainstorming merupakan metode awal untuk menentukan permasalahan yang dialami oleh para tenant sebagai peserta kegiatan ini. Kegiatan ini disebut sebagai kegiatan curah pendapat. Para tenant diminta untuk menuangkan ide, baik masalah maupun solusi yang ingin diperoleh melalui program pelatihan komptensi komunikasi ini. Pada tahap kedua, Peningkatan Kapasitas melalui Pelatihan. Pelatihan ini dilakukan tiga sesi, yakni: Sesi I fokus pada keterampilan komunikasi entrepreneur (baik secara langsung maupun by media), sesi II adalah practice of communication competence dan sesi III adalah presentasi bisnis para tenant. Sesi ketiga program ini dilakukan Monitoring dan evaluasi. Tahap ini dilakukan melalui pretest dan post test.

\section{HASIL DAN PEMBAHASAN}

Kegiatan Pelatihan Kompetensi Komunikasi untuk Pebisnis Pemula terdiri atas 3 tahap yakni:

\section{a) Tahap Brainstorming}

Pada tahap ini, kegiatan dilakukan dengan metode Diskusi Terarah (Focus Group Discussion - FGD). FGD diikuti oleh 20 orang peserta program PPK UIR 2020 bersama dengan Tim Pengabdian yang terdiri dari 4 orang dosen dan Tim Pelaksana yang berasal dari Mahasiswa. FGD dilakukan melalui aplikasi Zoom Meeting pada tanggal 20 Juni 2020. Berdasarkan hasil FGD diperoleh beberapa catatan terkait kompetensi komunikasi:

1) Pebisnis pemula belum memiliki kepercayaan diri yang tinggi untuk mengomunikasikan produk yang dijualnya

2) Pebisnis pemula belum memiliki konsep komunikasi bisnis yang mengintegrasikan teknologi komunikasi

3) Pebisnis pemula belum memiliki keterampilan presentasi bisnis yang baik.

Berdasarkan hasil curah pendapat tersebut, maka tim pengabdian memberikan peningkatan kapasitas entrepreneur melalui keterampilan komunikasi sehingga dapat meningkatkan kompetensi komunikasi para pebisnis pemula.

\section{b) Tahap Peningkatan Kapasitas melalui Pelatihan}

Kegiatan pelatihan ini terdiri dari dua sesi, yakni Sesi I fokus pada keterampilan komunikasi entrepreneur (baik secara langsung maupun by media) dan sesi II adalah presentasi bisnis para tenant. Sesi pelatihan pertama dilakukan pada hari Rabu, 24 Juni 2020, Jam 08.00 - 12.00 WIB bertempat di Hotel Zury Pekanbaru.

Pada sesi ini para peserta pelatihan diberikan materi tentang Komunikasi Verbal dan Non Verbal. Selanjutnya peserta juga diberi wawasan tentang bagaimana melakukan komunikasi bisnis melalui media, terutama media sosial. Narasumber dalam pelatihan ini adalah para praktisi dan akademisi yang memiliki kompetensi di bidang Komunikasi. 
Dalam kegiatan tersebut, peserta yang merupakan tenant dengan berbagai background bisnis yang baru dirintisnya juga diberikan sesi diskusi dan praktik. Pada sesi diskusi, dibantu oleh tim pelaksana, para peserta memberikan berbagai pertanyaan seputar masalah dan kendala komunikasi yang sering dihadapi, terutama bagaimana berkomunikasi dengan orang lain sebagai calon pembeli.

Sesi pelatihan kedua dilaksanakan pada hari yang sama yakni Rabu, 24 Juni 2020, Jam 13.00 - 16.00 WIB bertempat di Hotel Zury Pekanbaru. Pelatihan ini fokus pada keterampilan komunikasi dalam praktik.

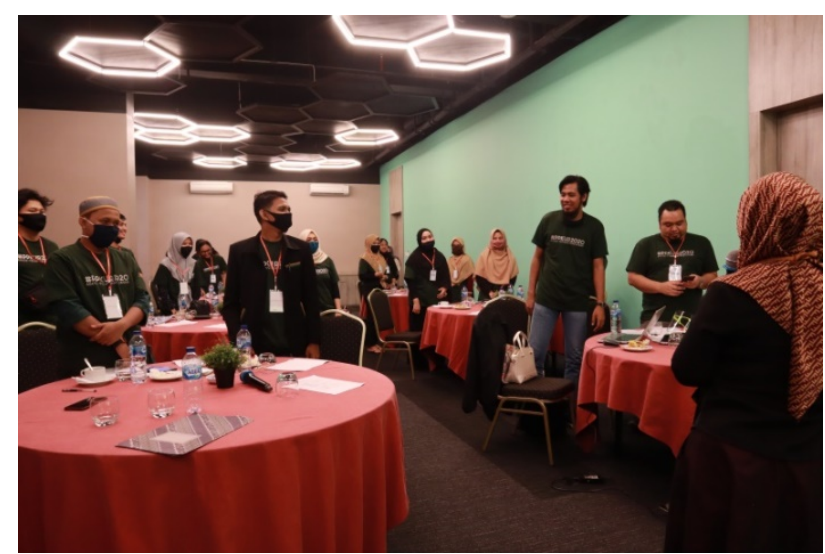

Gambar 1. Peserta Pelatihan melakukan Praktik “Eye to Eye Contact” dalam Pelatihan Kompetensi Komunikasi

Dalam kegiatan ini peserta memperoleh pengalaman praktis dan teoritis dari narasumber yang berkompeten. Kegiatan ini berlangsung selama 3 jam. Narasumber sekaligus memberikan contoh praktik secara langsung beberapa situasi dan kondisi pebisnis dalam menghadapi calon konsumen. Salah satu yang dipraktikkan adalah bagaimana melakukan "eye to eye" kepada calon konsumen. Peserta juga diberikan tips "smile services" dengan mempersilahkan seluruh peserta praktik kepada sesama peserta dan tim ke pelaksana. Menurut narasumber pelatihan, Asrinda Amalia, M. Si dikatakan bahwa setiap pebisnis harus menguasai skill komunikasi, diantaranya: Conversing, Writing, Presenting, Negotiating, Debating, Mediating dan Leading.

Berdasarkan kegiatan pelatihan kompetensi komunikasi kepada pebisnis pemula, berikut adalah model yang dapat diterapkan oleh pebisnis pemula dalam kaitannya dengan bagaimana membangun kompetensi komunikasi:

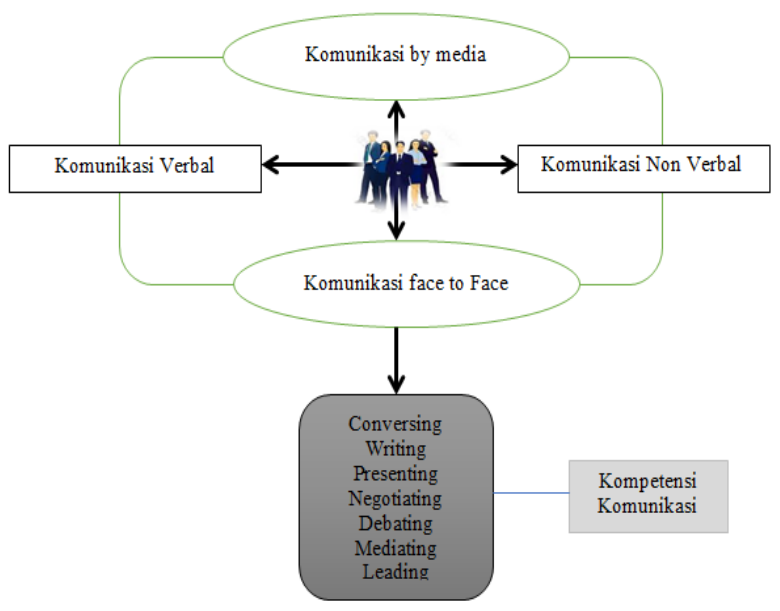

Gambar 2. Kompetensi Komunikasi untuk Pebisnis Pemula

Sesi ketiga dari kegiatan pelatihan kompetensi komunikasi adalah Presentasi Bisnis. Kegiatan tersebut dilakukan pada hari Jumat, 10 Juli 2020 bertempat di Hotel Ayola First Poin Pekanbaru jam $08.00-16.00$ WIB. Dalam kegiatan tersebut dihadiri oleh seluruh tim pengabdian, tim pelaksana dan 20 peserta pelatihan yang merupakan pebisnis pemula di Universitas Islam Riau.

Pelaksanaan kegiatan presentasi bisnis dimulai dengan membagi semua tenant kedalam dua kategori, yakni enam usaha Jasa dan dan 14 usaha Barang. Masing-masing peserta diberikan waktu 10 menit untuk presentasi usahanya, kemudian tim 
pengabdian (dosen) dan juga narasumber lain memberikan review terhadap presentasi yang dilakukan oleh peserta pelatihan. Review yang dilakukan meliputi: Teknik Presentasi, Kemampuan Persuasi dan Packaging Performing.
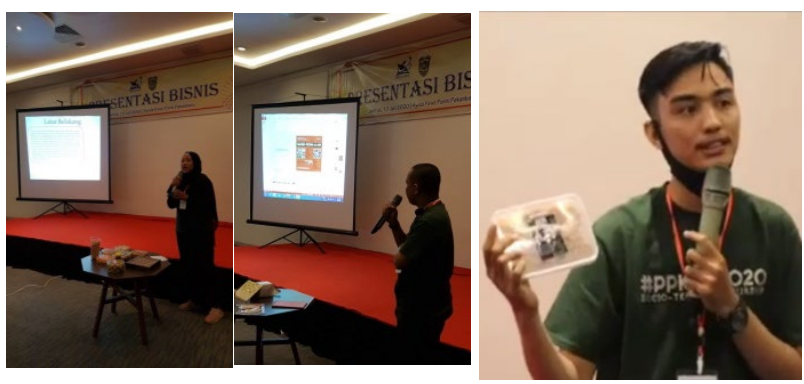

Gambar 3. Peserta Pelatihan melakukan Praktik Presentasi Bisnis

\section{c) Tahap Monitoring dan Evaluasi}

Dalam kegiatan Monitoring dan

Evaluasi dilakukan dengan melakukan observasi dan wawancara secara langsung kepada peserta terkait kompetensi komunikasi yang dimiliki oleh peserta setelah mengikuti kegiatan pelatihan kompetensi komunikasi. Observasi dilakukan baik secara langsung kepada para tenant juga melalui media social yang digunakan oleh tenant sebagai media promosi produknya.

Hasil observasi diperoleh bahwa semua tenant telah melakukan perbaikan baik secara komunikasi verbal maupun nonverbal. Selain itu tenant juga mengakui melalui wawancara bahwa kegiatan pelatihan ini memberikan dampak positif yang besar dalam sebagai pebisnis, terutama dalam meningkatkan kompetensi komunikasi. Namun, peserta mengatakan bahwa waktu pelatihan masih kurang. Hal ini senada dengan kegiatan pelatihan yang telah dilakukan di Kota Bau-Bau yakni pelatihan peningkatan kemampuan berbahasa
Inggris yang telah memberikan manfaat positif bagi remaja di kota tersebut (Dahniar, Nurmaya, \& Irsan, 2018).

\section{KESIMPULAN DAN SARAN}

Kesimpulan dari kegiatan pelatihan kompetensi komunikasi bagi para pebisnis pemula adalah:

a. Kompetensi komunikasi bagi pebisnis pemula sangat diperlukan guna meningkatkan performance sebagai pebisnis.

b. Pelatihan kompetensi komunikasi ini terdiri atas tiga kegiatan yang terintegrasi, yakni pelatihan verbal dan nonverbal komunikasi, pelatihan presentasi bisnis dan praktik presentasi tenant.

c. Dari hasil monitoring dan evaluasi diperoleh bahwa kegiatan pelatihan ini memberikan dampak positif terutama dalam peningkatan kompetensi komunikasi, namun masih terdapat kekurangan yakni waktu pelatihan masih terbatas.

\section{PENUTUP}

Penulis mengucapkan terima kasih kepada RISTEK-BRIN dan LPPM Universitas Islam Riau yang telah memberikan dukungan financial terhadap pengabdian ini. Penghargaan setinggitingginya juga disampaikan kepada seluruh narasumber pelatihan, tim pelaksana dan tim pengabdian dosen Universitas Islam Riau.

\section{REFERENSI}

Agustin, Dyan, Dwi, S. W. (2020). Pembuatan Bros Dari Bahan Manik Dan Limbah Kawat Untuk Pelatihan Wirausaha Ibu Pkk Perumahan Sentra Alam Sidoarjo. Pelayanan Dan Pengabdian Masyarakat (PAMAS), 4(1), 27-37. Retrieved from http://ejournal.urindo.ac.id/index.php/P AMAS/article/view/779/607 
Dahniar, N., Nurmaya, A. L., \& Irsan. (2018). Pelatihan Kemampuan Berbicara Bahasa Inggris dalam Percakapan Sehari-hari Bagi Para Pemuda di Kota Bau-Bau. Jurnal PPM Membangun, 2(1), 66-73. https://doi.org/https://doi.org/10.35326/ pkm.v1i2.67

Marganingsih, A., Pelipa, E. D., \& Astuti, S. (2018). Pelatihan Komunikasi Efektif dalam Rangka Membina Keterampilan Berwirausaha Siswa di SMPN 4 Sintang. Pengabdian Masyarakat Katulistiwa, 1(April), 11-22.

Merieska, P., \& Meiyanto, I. J. K. S. (2017). Passion Berwirausaha pada Pengusaha Muda. Psychology, 3(1), 13-24.

Moekahar, F., \& Handayani, B. (2019). Fenomenologi Literasi Media Pada Remaja Di Kota Pekanbaru. Ranah Komunikasi, 3, 12-22. https://doi.org/https://doi.org/10.25077/r k.3.1.12-22.2019

Moekahar, F., Sukri, A., \& Amalia, A. (2020). Peningkatan Softskill Remaja Masjid Fastabiqul Khairat Kelurahan Sungai Sibam Kota Pekanbaru.
AMALIAH

Pengabdian Untuk Mu NegeRi, 4(1), 25-28.

https://doi.org/https://doi.org/10.37859/j pumri.v4i1.1779

Noya, S. (2017). Mencetak Wirausaha Muda Universitas Ma Chung. $A B M$ Mengabdi, 3(December 2016), 67-78.

Rakib, M. (2010). Pengaruh Model Komunikasi Wirausaha, Pembelajaran Wirausaha, dan Sikap Kewirausahaan terhadap Kinerja Usaha Kecil. Jurnal Ilmu Pendidikan, Jilid 17 N, 121-129. Retrieved from https://media.neliti.com/media/publicati ons/114407-ID-model-komunikasiwirausaha-pembelajaran.pdf

Sulistiyowati, W., Agustini, I., \& Fitriyah, H. (2016). Peningkatan Kapasitas Entrepreneurship melalui Pelatihan dan Magang bagi Tenant di Universitas Muhammadiyah Sidoarjo. Pengabdian MAsyarakat, 2, 1-5. Retrieved from https://core.ac.uk/download/pdf/132576 403.pdf 